\title{
Ground-dwelling arthropod communities present in three types of Cantabrian (NW Spain) heathland grazed by sheep or goats
}

\author{
Rocío ROSA GARCÍA ${ }^{1}$, Francisco J. OCHARAN ${ }^{2}$, Berta M. JÁUREGUI ${ }^{1}$, URCesino GARCÍA ${ }^{1}$, \\ Koldo OSORO ${ }^{1}$ and RAFAEL CELAYA ${ }^{1}$ \\ ${ }^{1}$ Servicio Regional de Investigación y Desarrollo Agroalimentario, Apdo. 13, 33300 Villaviciosa, Asturias, Spain; \\ e-mail: entomteam@hotmail.com \\ ${ }^{2}$ Departamento de Biología de Organismos y Sistemas, Universidad de Oviedo, C/ Catedrático Rodrigo Uría s/n, 33071 Oviedo, \\ Asturias, Spain
}

Key words. Ground-dwelling arthropods, Lycosidae, Opiliones, Carabidae, diversity, grazing, heathland, sheep, goat

\begin{abstract}
The abundance, diversity and community composition of ground-dwelling arthropods present in three different types of Cantabrian heathland grazed by small ruminants were studied. A factorial design of three vegetation types (heather-, gorse- or grassdominated) and two grazer species (sheep or goats) with two replicates was established in twelve 0.6 ha paddocks. Ground-dwelling arthropods (Araneae, Opiliones, Isopoda, Julida, Microcoryphia, Hemiptera, Coleoptera and Hymenoptera) were recorded using pitfall traps and plant cover and canopy height assessed in each paddock in 2005, 2006 and 2007. Higher abundances and more families of ground dwelling arthropods were recorded in areas dominated by heather, although certain species were more numerous in areas dominated by grass. The direct effects of the grazer species on arthropods were subtle compared to their great effect on the vegetation. Significant interactions between grazer species and vegetation were observed for some taxa and the overall arthropod community composition. Gradient analyses indicate that arthropod assemblages that include Lycosidae, Opiliones and Carabidae differed between vegetation types and years, but are not affected by the grazer species. Our study shows that areas dominated by shrubby and diverse heather had the highest diversity and abundance of arthropods. Species composition varied along a gradient in the structure of the vegetation, which in turn was modified by the grazer species.
\end{abstract}

\section{INTRODUCTION}

Heathland is a semi-natural shrubland habitat that occupied large areas in the humid regions of Western Europe in the past (Gimingham, 1992), and currently the high rates of loss and degradation of this habitat are of special concern in many countries (Farrel, 1989; Piessens \& Hermy, 2006) and their conservation the aim of various agro-environmental programs (Brown, 1990; Thompson et al., 1995). However, Cantabrian heathlands are special from the environmental and socioeconomical points of view. In the past century they were a major component of the landscape in the Cantabrian region (northern Spain). Heathlands cover $21 \%$ of the total surface of Asturias (Álvarez et al., 2004), mostly in mountainous areas subject to public or communal use, and the rest in fields abandoned during the rural exodus resulting from industrialization in the 1950s and 1960s (Osoro et al., 1999). Furthermore, much of this heathland was affected by wildfires over the last twenty years, which caused many social, economic and environmental problems (Osoro et al., 1999).

Heathlands were traditionally grazed by livestock, of which the small ruminants and horses are better adapted to feed on the nutritionally poor vegetation than cattle (Osoro et al., 2009). Differences in foraging behaviour of sheep and goats can influence the structure of the vegetation and botanical composition of these heathlands (Celaya et al., 2007; Jáuregui et al., 2007, 2009). Goats are browsers adapted to feed on shrubby vegetation, whereas sheep prefer to graze on herbaceous vegetation (Radcliffe, 1985; Celaya et al., 2008). Therefore, goat grazing reduces the woody phytomass and promotes higher herbaceous cover more than sheep grazing, although control of shrubs by goats may also depend on the botanical composition and its successional stage (Jáuregui et al., 2009).

The modification of vegetation by grazing can also affect the fauna, especially the arthropods (e.g., Morris, 1990; Gibson \& Brown, 1991; Gibson et al., 1992a, b; Gardner et al., 1997; Dennis et al., 1998, 2001; González Megías et al., 2004). To date, most studies have focused on the effect of grazing by cattle, sheep or wild ungulates on grasslands, and there are no experiments comparing the effects of grazing by animals on shrubland communities. Focusing on heathlands, Newton et al. (2009) have recently pointed out the need for improved monitoring and experimental analysis of the effectiveness of management in order to strengthen the case for managing heathlands. Furthermore, as the EU Common Agrarian Policy is moving towards a more local expression of agrienvironmental priorities (Evans et al., 2003), it is important to have a better knowledge of the effect of different management practices on biodiversity.

Amongst terrestrial arthropods, harvestmen (Opiliones), wolf spiders (Araneae: Lycosidae) and ground beetles (Coleoptera: Carabidae) show distinct associations with specific habitats and are sensitive to habitat modification 
(e.g., Sankey \& Savory, 1974; Rainio \& Niemelä, 2003; Vohland et al., 2005). While certain Coleoptera might be more affected by changes in the floristic composition than in the structural features, other groups such as Araneae, Opiliones, Hemiptera or Orthoptera respond mainly to the structural characteristics of the plant canopy (Gardner, 1991; Gibson et al., 1992a; Dennis et al., 1998; Wettstein \& Schmid, 1999; Rosa Garcia et al., 2009). They are also widely distributed, diverse and relatively well-known taxonomically, making them potential bioindicators. Furthermore, using more than one taxon has the advantage of testing the generality of observed patterns, and it is desirable to include a range of taxa when using bioindicators (Rainio \& Niemelä, 2003).

An experiment originally established to investigate the effects of two grazer species (sheep and goats) on three types of shrubland vegetation (heather, gorse or grass dominated) provided the opportunity to analyse the effects of such treatments on the associated arthropod fauna. The results are expected to provide insights into the effects that livestock grazing has on the biodiversity of these areas and result in the development of sustainable management systems for different types of vegetation. Arthropod fauna is expected to be influenced by the structural composition of the vegetation and the grazing management. Furthermore, because of the heterogeneous habitat preferences of the arthropod fauna, the different taxa are expected to respond differently to the same alteration. The current study aimed to test the following hypotheses: (a) the abundance and diversity of arthropods in shrubby and structurally more complex vegetation is greater than in simpler grass dominated vegetation; (b) sheep and goat grazing affect the arthropod fauna differently through their different effect on vegetation; and (c) grazing effects depend also on the type of vegetation, i.e., is there is an interaction between both factors.

\section{MATERIAL AND METHODS}

\section{Study site}

The field site is located at Illano, Asturias, north-west Spain $\left(43^{\circ} 21^{\prime} \mathrm{N}, 6^{\circ} 53^{\prime} \mathrm{W}\right)$. Its altitude ranges from 870 to $960 \mathrm{~m}$ a.s. 1 . The ranker soils are typically acidic $(3.8-4.0 \mathrm{pH})$ and shallow. Mean temperature is $10.0^{\circ} \mathrm{C}$ and mean annual precipitation 1536 $\mathrm{mm}$. During the sampling periods (from June till August), mean temperature was $16.6,16.0$ and $13.9^{\circ} \mathrm{C}$ in 2005,2006 and 2007 , respectively. Precipitation was 48, 154 and $247 \mathrm{~mm}$ during the same periods.

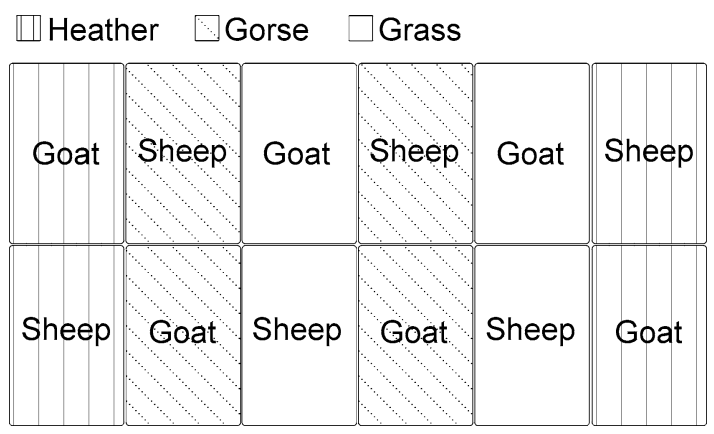

Fig. 1. Experimental layout, with two grazer species (goat or sheep) and three types of vegetation (heather, gorse or grass dominated shrublands) in 12 plots, each of 0.6 ha.

The characteristic plant community is a heather gorse shrubland, where the dominant dwarf heather species are Erica umbellata L., E. cinerea L. and Calluna vulgaris (L.) Hull. Gorse, a thorny woody legume, is represented by Ulex gallii Planchon, and herbaceous plants mainly by the grasses Pseudarrhenatherum longifolium (Thore) Rouy and Agrostis curtisii Kerguélen, among others.

\section{Experimental design}

The factorial experiment consisted of three vegetation types (heather, gorse or grass dominated shubland) and two livestock species (sheep or goats) with two replicates. Prior to the experiment, in May 2001, a heathland area of 5 ha was superficially burned and afterwards divided into four adjacent 1.2 ha paddocks. Sheep or goats were randomly allocated to these paddocks and grazed there from September 2001 to January 2002, and from May 2002 to November 2002. In the spring 2003 either gorse or grass dominated shrubland was already present in the paddocks grazed by the sheep and goats, respectively (see Jáuregui et al., 2007 for more details). Two surrounding unburned heather dominated areas were then added to the experiment, giving a total of six fields: two previously burned and goat grazed (grass dominated), two burned and sheep grazed (gorse dominated) and two unburned and ungrazed (heather dominated).

In May 2003 each of the six fields was divided into two 0.6 ha paddocks, and sheep (Gallega breed, average $38 \mathrm{~kg}$ live weight) or goat (Cashmere breed, average $35 \mathrm{~kg}$ live weight) treatments randomly allocated within each pair (Fig. 1). Stocking rate was 10 animals/ha (6 adult non-lactating females per paddock). Flocks were managed from May to October-November (depending on weather conditions) until the year 2007. An exception was the year 2005, when animals were removed at the end of August due to a severe summer drought.

TABLE 1. Plant cover, canopy height and phytomass of the different types of vegetation in the heather, gorse and grass dominated shrublands studied. Means \pm SE for the four paddocks sampled in 2005, 2006 and 2007.

\begin{tabular}{|c|c|c|c|}
\hline & Heather dominated & Gorse dominated & Grass dominated \\
\hline \multicolumn{4}{|l|}{ Cover $(\%)$} \\
\hline Heather & $48.5 \pm 1.3$ & $3.3 \pm 0.4$ & $3.3 \pm 0.3$ \\
\hline Gorse & $21.8 \pm 2.5$ & $60.8 \pm 2.8$ & $45.4 \pm 3.7$ \\
\hline Other shrubs & $3.6 \pm 1.3$ & $0.2 \pm 0.1$ & $0.0 \pm 0.0$ \\
\hline Herbaceous & $16.8 \pm 2.5$ & $25.3 \pm 2.3$ & $38.9 \pm 5.2$ \\
\hline Rest (litter, bare ground) & $9.3 \pm 0.8$ & $10.4 \pm 0.6$ & $12.4 \pm 2.0$ \\
\hline Canopy height $(\mathrm{cm})$ & $20.1 \pm 1.2$ & $16.5 \pm 0.8$ & $12.1 \pm 1.1$ \\
\hline Phytomass (kg dry matter.ha ${ }^{-1}$ ) & $22,177 \pm 1,405$ & $18,053 \pm 1,721$ & $15,359 \pm 1,996$ \\
\hline
\end{tabular}




\section{Sampling method}

Plant cover and height were measured once a year using a point-quadrat method (Grant, 1981). Three hundred vertical contacts were recorded along three permanent transects within each paddock at the beginning of each grazing season (May). Simultaneously, phytomass samples were collected from five randomly located quadrats of $0.2 \times 1 \mathrm{~m}$ in each paddock. Samples were dried in a forced-air oven at $80^{\circ} \mathrm{C}$ for $24 \mathrm{~h}$ and the weight of the dry matter (DM) recorded. The characteristics of the different types of vegetation are summarized in Table 1 (for more details on vegetation dynamics see Jáuregui et al., 2009).

Epigeic arthropods were sampled using pitfall traps (plastic cups, $10 \mathrm{~cm}$ diameter, $1 / 3$ filled with a solution of water and detergent). This method is adequate for collecting invertebrates living close to the soil surface (e.g., Mommertz et al., 1996; Duelli et al., 1999) and provides a measure of their activitydensity, rather than total density (Uetz \& Unzicker, 1976). Activity-density will be referred to as abundance in the present work. Twelve pitfall traps were placed $4 \mathrm{~m}$ apart along a transect in each paddock. Each trap was covered with a tile to protect it from rain and prevent it from being pulled out or trodden on by livestock. The sampling of ground-dwelling arthropods was carried out on five occasions: late June and mid August 2005, late June 2006, and late June and mid August 2007. Data from the second sampling within the year 2006 were lost because many traps were flooded. The period of pitfall trapping lasted for five days on each sampling occasion. Adult specimens of wolf spiders (Araneae: Lycosidae), harvestmen (Opiliones) and ground beetles (Coleoptera: Carabidae) were indentified to species or morphospecies using identification keys such as Simon (1879), Martens (1978) and Barrientos (2004) for Opiliones, Roberts (1993, 1995) for Lycosidae, and Forel \& Leplat (2001) and Ortuño \& Marcos (2002) for Carabidae, among others. We had permission from national and local authorities to collect the arthropods, vroucher specimens of which were preserved in $70 \%$ alcohol.

\section{Statistical analysis}

Data from the 12 traps in each paddock were pooled, which avoided the problem of pseudoreplication and variations in capture efficiency attributable to the locations of the individual traps. Repeated measures ANOVA was used to analyse the effects of grazer species and vegetation type on the arthropod data (abundance and family or species richness). Species abundance data were $\log _{10}(\mathrm{x}+1)$ transformed to better meet the assumptions of normality and homogeneity of variance. The analyses were performed using a mixed model procedure (PROC MIXED, SAS Institute, 1999). The model consisted of fixed effects of grazer species $(\mathrm{Gr})$, vegetation type $(\mathrm{Vg})$, year (Yr, with three repeated measures) and full factorial interactions. Data from the first sampling period (June) within each of the three years was included in this analysis. When searching for seasonal differences, data from late spring (June) and midsummer (August) during the years 2005 and 2007 were included in the analysis. The season model consisted of $\mathrm{Gr}, \mathrm{Vg}$, $\mathrm{Yr}$ (with two repeated measures), season (Ss, with two repeated measures) and full factorial interactions. Each experimental unit was considered a subject and corresponded to each paddock. The best model for the covariance structure across time was selected according to the corrected Akaike Information Criteria (Burnham \& Anderson, 2002). The Bonferroni post hoc test was used to examine pairwise differences between means.

The response of the arthropod community to the treatments was analysed by constrained ordination of multivariate data $\left[\log _{10}(\mathrm{x}+1)\right.$ transformed abundances $]$ on wolf spiders (Araneae: Lycosidae), harvestmen (Opiliones) and groundbeetles (Coleoptera: Carabidae). The length of the gradient of the first axis (2.817) of a preliminary detrended correspondence analysis (DCA) confirmed the appropriateness of the subsequent redundancy analysis (RDA) (Lepš \& Šmilauer, 2003). The RDA was followed by a Monte Carlo Permutation test (4999 permutations). The following explanatory variables were used: $\mathrm{Yr}$ (2005, 2006, 2007), Gr (sheep, goat), Vg (heather, gorse or grass dominated) and the two-way interactions Gr*Yr, $\mathrm{Vg}^{*} \mathrm{Yr}$ and $\mathrm{Gr}^{*} \mathrm{Vg}$. Data from the first sampling season within each year was included in this analysis. Split-plot permutation tests were used where split-plots were the annual observations within each whole plot (paddock). When seasonal differences were analysed, the data recorded during the two sampling seasons in 2005 and 2007 were entered as explanatory variables. RDA was conducted with and without standardization by sample norm. Another RDA was conducted to calculate the variability in fauna assemblages accounted for by the environmental variables (plant cover, height and phytomass), based on the data from the first samples in each year. Ordination analyses on standardized and non-standardized data were consistent so only results from non-standardized data are shown. All ordinations were conducted using the software CANOCO version 4.5 for Windows (ter Braak \& Šmilauer, 2002).

TABLE 2. Abundance (catches in 12 pitfall traps per paddock) of arthropod taxa present in three types of Cantabrian heathland (heather, gorse or grass dominated) grazed by sheep or goats. Means are for two paddocks per treatment and three years. Results of repeated-measures ANOVA for the effects of grazer species $(\mathrm{Gr})$, vegetation type $(\mathrm{Vg})$ and year (Yr) on the fauna (NS, not significant; $\left.{ }^{+} P<0.1 ; * P<0.05 ; * * P<0.01 ; * * * P<0.001\right)$.

\begin{tabular}{|c|c|c|c|c|c|c|c|c|c|c|c|}
\hline \multirow{2}{*}{$\begin{array}{l}\text { Vegetation } \\
\text { Grazer species }\end{array}$} & \multicolumn{2}{|c|}{ Heather } & \multicolumn{2}{|c|}{ Gorse } & \multicolumn{2}{|c|}{ Grass } & \multirow{2}{*}{ SEM } & \multicolumn{4}{|c|}{ Significance } \\
\hline & Sheep & Goat & Sheep & Goat & Sheep & Goat & & $\mathrm{Gr}$ & $\mathrm{Vg}$ & $\mathrm{Yr}$ & Gr*Yr \\
\hline Total Arthropoda & 456.0 & 338.5 & 172.0 & 183.7 & 231.5 & 231.3 & 94.51 & NS & + & NS & NS \\
\hline Order Araneae & 39.5 & 34.5 & 25.7 & 31.8 & 28.5 & 34.8 & 3.75 & NS & NS & NS & $*$ \\
\hline Order Opiliones & 12.8 & 8.8 & 3.0 & 5.3 & 2.8 & 4.0 & 1.75 & NS & $* * *$ & NS & NS \\
\hline Order Isopoda & 2.0 & 1.5 & 8.5 & 7.2 & 8.7 & 7.3 & 3.39 & NS & NS & $* *$ & NS \\
\hline Order Julida & 5.5 & 1.7 & 0.2 & 0.8 & 0.8 & 0.8 & 1.91 & NS & NS & $*$ & NS \\
\hline Order Microcoryphia & 3.0 & 7.3 & 2.5 & 4.0 & 2.5 & 2.5 & 1.08 & $*$ & + & NS & NS \\
\hline Order Hemiptera & 3.0 & 3.7 & 2.3 & 4.0 & 2.2 & 1.8 & 0.89 & NS & NS & NS & NS \\
\hline Order Coleoptera & 48.7 & 27.0 & 20.8 & 15.0 & 20.8 & 19.7 & 11.95 & NS & NS & NS & NS \\
\hline Family Formicidae & 336.8 & 250.2 & 102.0 & 113.2 & 161.3 & 158.0 & 88.00 & NS & NS & NS & NS \\
\hline Others & 3.3 & 2.8 & 6.5 & 1.8 & 2.5 & 1.6 & 1.45 & NS & NS & $*$ & NS \\
\hline
\end{tabular}

The interactions $\mathrm{Gr} * \mathrm{Vg}, \mathrm{Vg} * \mathrm{Yr}$, and $\mathrm{Gr}^{*} \mathrm{Vg} *$ Yr were NS for all dependent variables. 
TABLE 3. Family and species richness and abundance of main arthropod taxa recorded in three types of Cantabrian heathland (heather, gorse or grass dominated) grazed by sheep or goats. Means are for two paddocks per treatment and three years. Results of repeated-measures ANOVA for the effects of grazer species ( $\mathrm{Gr})$, vegetation type (Vg) and year ( $\mathrm{Yr}$ ) on the fauna (NS, not significant; $\left.{ }^{+} P<0.1 ;{ }^{*} P<0.05 ; * * P<0.01 ; * * * P<0.001\right)$.

\begin{tabular}{|c|c|c|c|c|c|c|c|c|c|c|c|}
\hline \multirow{2}{*}{$\begin{array}{l}\text { Vegetation } \\
\text { Grazer species }\end{array}$} & \multicolumn{2}{|c|}{ Heather } & \multicolumn{2}{|c|}{ Gorse } & \multicolumn{2}{|c|}{ Grass } & \multirow{2}{*}{ SEM } & \multicolumn{4}{|c|}{ Significance } \\
\hline & Sheep & Goat & Sheep & Goat & Sheep & Goat & & $\mathrm{Gr}$ & $\mathrm{Vg}$ & $\mathrm{Yr}$ & Gr*Vg \\
\hline \multicolumn{12}{|l|}{ Family richness: } \\
\hline Arthropoda & 25.33 & 23.17 & 18.67 & 22.67 & 21.17 & 19.17 & 1.277 & NS & $* *$ & $*$ & $*$ \\
\hline \multicolumn{12}{|l|}{ Species richness: } \\
\hline Lycosidae & 2.83 & 3.83 & 3.17 & 3.33 & 3.83 & 3.50 & 0.642 & NS & NS & $* *$ & NS \\
\hline Opiliones & 3.67 & 3.17 & 2.00 & 2.67 & 1.83 & 1.33 & 0.701 & NS & + & $*$ & NS \\
\hline Carabidae & 2.83 & 2.33 & 1.50 & 2.00 & 1.83 & 1.67 & 0.505 & NS & NS & NS & NS \\
\hline \multicolumn{12}{|l|}{ Activity density: } \\
\hline Linyphiidae & 1.50 & 2.17 & 1.17 & 2.33 & 0.83 & 2.67 & 0.544 & $*$ & NS & NS & NS \\
\hline Lycosidae & 10.83 & 14.17 & 10.83 & 10.50 & 13.33 & 19.83 & 3.729 & NS & NS & NS & NS \\
\hline P. pullata & 0.50 & 0.67 & 3.17 & 0.67 & 0.67 & 10.33 & 1.732 & NS & $*$ & $*$ & $* *$ \\
\hline Liocranidae & 3.00 & 2.50 & 0.67 & 1.00 & 0.00 & 0.17 & 0.269 & NS & $* * *$ & $*$ & NS \\
\hline Gnaphosidae & 8.67 & 6.67 & 4.83 & 7.00 & 4.50 & 4.33 & 1.179 & NS & $*$ & $* * *$ & NS \\
\hline Agelenidae & 9.83 & 6.50 & 5.33 & 8.17 & 6.67 & 4.83 & 1.202 & NS & NS & NS & $*$ \\
\hline Phalangiidae & 6.00 & 4.00 & 1.50 & 2.17 & 1.50 & 2.67 & 1.383 & NS & $* *$ & $*$ & NS \\
\hline H. laranderas & 5.67 & 3.83 & 0.83 & 2.00 & 0.83 & 0.17 & 1.352 & NS & $* * *$ & $*$ & NS \\
\hline Carabidae & 12.17 & 3.67 & 2.50 & 2.00 & 2.17 & 2.00 & 3.589 & NS & $*$ & NS & NS \\
\hline
\end{tabular}

The interactions Gr*Yr, $\mathrm{Vg} * \mathrm{Yr}$, and $\mathrm{Gr}^{*} \mathrm{Vg}^{*} \mathrm{Yr}$ were NS for all dependent variables.

\section{RESULTS}

\section{Vegetation}

The data on plant cover, canopy height and phytomass recorded during the current study are indicated in Table 1 for each type of vegetation (i.e., heather, gorse and grass dominated). Plant dynamics differed between vegetation types, and grazing effects were more pronounced in grass dominated than in heather dominated shrublands (Jáuregui et al., 2009). Globally, shrub cover and height decreased while herbaceous cover increased more in paddocks grazed by goats than by sheep.

\section{Abundance and richness of ground-dwelling arthropods}

A total of 15,071 arthropods from 22 orders and 75 families were collected. Ants (Hymenoptera, Formicidae) comprised $60.1 \%$ of the total catch, followed by Araneae $(11.7 \%)$, Coleoptera $(7.8 \%)$ and Opiliones $(2.3 \%)$. The highest number of families were recorded for the orders Araneae and Coleoptera $(24.0 \%$ each), followed by Hemiptera (13.3\%) and Opiliones (10.7\%).

Total arthropod abundance varied between vegetation types $\left(F_{2,18}=3.44, P=0.054\right)$ but was not affected by the grazer species, year or season (Table 2). There was a near-significant trend towards higher catches $(P=0.060)$ in heather than in gorse dominated paddocks. A significant interaction effect between vegetation type and grazer species was detected on the number of arthropod families $\left(F_{2,18}=3.78, P=0.042\right)$. More families were recorded in heather than in gorse dominated paddocks when grazed by sheep $(P=0.025)$, but there were no significant differences when grazed by goats (Table 3 ). The number of families varied significantly between years $\left(F_{2,18}=4.59, P\right.$ $=0.024)$ and fewer families were recorded in 2005 than in $2007(P=0.032)$. No differences between seasons were observed.

The total catch and the number of families of spiders (Araneae) did not vary significantly between vegetation types, grazer species, years or seasons. The abundance of linyphids (Linyphiidae) was unaffected by the type of vegetation, and higher catches were recorded in goat grazed than in sheep grazed paddocks $\left(F_{1,18}=7.56, P=\right.$ 0.013). Neither the abundance of wolf spiders (Lycosidae) nor their species richness differed between vegetation types or grazer species. The abundance of the most common wolf spider Pardosa pullata (Clerck, 1757) varied between vegetation types $\left(F_{2,18}=4.52, P=0.026\right)$. More individuals were captured in grass than in heather dominated vegetation $(P=0.024)$, and within grass dominated paddocks, there were higher abundances when grazed by goats than by sheep $(P=0.013)$. Higher catches of this species were also recorded in grass than in both gorse and heather dominated paddocks grazed by goats $(P<0.05)$, while no differences between vegetation types were detected in paddocks grazed by sheep (Table $3)$.

The abundances of Liocranidae $\left(F_{2,18}=59.1, P<0.001\right)$ and Gnaphosidae $\left(F_{2,18}=3.81, P=0.042\right)$ also differed between vegetation types. More liocranids were recorded in heather than in grass or gorse dominated paddocks $(P<$ $0.001)$, while higher catches of Gnaphosidae $(P=0.039)$ were recorded in heather than in gorse dominated paddocks (Table 3).

The abundance $\left(F_{2,18}=10.86, P<0.001\right)$ and species richness $\left(F_{2,18}=3.46, P=0.053\right)$ of Opiliones differed between vegetation types but were unaffected by the grazer species. Higher catches $(P<0.001)$ were recorded in heather than in grass and gorse dominated paddocks 


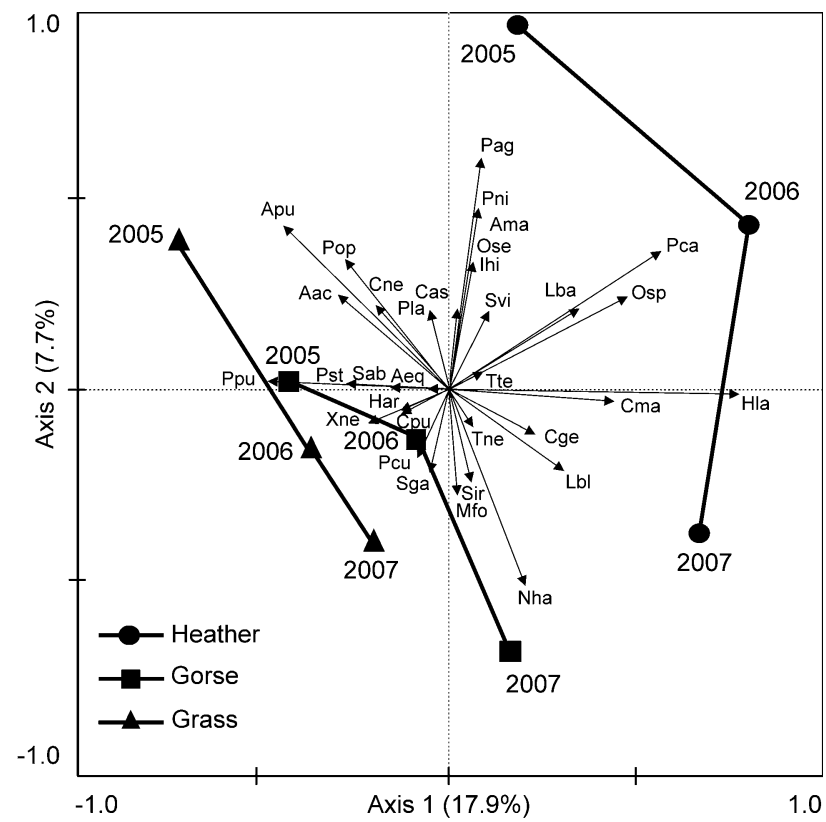

Fig. 2. Ordination diagram of ground-dwelling arthropod species based on a non-standardized RDA of the interactions between year (2005, 2006 and 2007) and type of vegetation (heather, gorse or grass dominated). For arthropod species abbreviations see Appendix.

(Table 3). Species richness also tended to be higher in heather than in grass dominated paddocks $(P=0.052)$. The abundance of this order was similar across years, but its richness varied between years $\left(F_{2,18}=5.92, P=0.011\right)$ and fewer species were recorded in 2006 than in $2007(P$ $=0.009)$. The abundance of the family Phalangiidae $\left(F_{2,18}\right.$ $=6.24, P=0.009)$ and the species Homalenotus laranderas Grasshoff, $1959\left(F_{2,18}=13.21, P<0.001\right)$ also differed between vegetation types, and were higher in heather dominated than in the other two types of vegetation (Table 3).

The abundance and family richness of the order Coleoptera did not vary between vegetation types, grazer species or years, although more families were recorded in late spring than in summer $\left(F_{1,24}=4.26, P=0.049\right)$. The abundance and species richness of carabids (Carabidae) were also unaffected by the type of vegetation or grazer species.

The remaining orders of arthropods were not affected by the type of vegetation or grazer species (Table 2), except for the higher abundances of Microcoryphia in paddocks grazed by goats than by sheep $\left(F_{1,18}=4.88, P=\right.$ 0.040).

\section{Arthropod community composition}

Redundancy analysis showed that arthropod community composition greatly differed between vegetation types $(P$ $<0.05$; Table 4) mainly due to the contribution of the heather dominated vegetation $(F=6.03, P=0.006)$. The temporal trend in species composition was not independent of the type of vegetation $(P<0.05)$. There is a gradient of types of vegetation associated with axis 1 (from grass dominated towards gorse and heather dominated areas) and time with axis 2 (from the first to the last year) (Fig. 2). In each year, arthropod assemblages associated with heather dominated vegetation clearly differed from those in gorse and grass dominated vegetation, which have more similar assemblages.

Arthropod assemblages were not affected by the grazer species or the interaction between grazer species and year (Table 4). On the contrary, they differed in the interaction between grazer species and vegetation type $(P<0.05$; Fig. 3) and most of the variance was explained by the grass dominated vegetation grazed by goats $(F=5.02, P$ $<0.05)$, as well as heather dominated grazed by either

TABLE 4. Summary of the results of RDA analyses performed on the arthropod assemblages recorded during the three years in three types of heathland vegetation (heather, gorse, or grass dominated) grazed either by sheep or goats.

\begin{tabular}{|c|c|c|c|c|c|c|c|c|}
\hline Hypothesis tested & Env. & Cov. & Perm. & $\%$ exp. & $F$ first & $F$ all & $P$ first & $P$ all \\
\hline $\begin{array}{l}\text { Did species composition differ } \\
\text { between vegetation types? }\end{array}$ & $\mathrm{Vg}$ & Yr & Free/no & 48.3 & 6.22 & 3.75 & 0.008 & 0.016 \\
\hline $\begin{array}{l}\text { Did development differ between } \\
\text { vegetation types? }\end{array}$ & $\mathrm{Vg} * \mathrm{Yr}$ & Yr, PlotID & Free/free & 24.6 & 2.29 & 1.47 & 0.031 & 0.014 \\
\hline $\begin{array}{l}\text { Did species composition differ } \\
\text { between grazers? }\end{array}$ & $\mathrm{Gr}$ & Yr & Free/no & 53.3 & & 0.69 & & 0.939 \\
\hline $\begin{array}{l}\text { Did development differ between } \\
\text { grazing treatments? }\end{array}$ & Gr*Yr & Yr, PlotID & Free/free & 40.0 & 1.07 & 0.78 & 0.677 & 0.776 \\
\hline $\begin{array}{l}\text { Did grazer*vegetation interaction } \\
\text { affect fauna composition? }\end{array}$ & $\mathrm{Gr} * \mathrm{Vg}$ & Yr & Free/no & 34.4 & 7.01 & 3.06 & 0.019 & 0.014 \\
\hline $\begin{array}{l}\text { Did species composition differ } \\
\text { between years? }\end{array}$ & Yr & $\mathrm{Gr}, \mathrm{Vg}$ & No/free & 45.7 & 3.79 & 2.82 & 0.000 & 0.000 \\
\hline $\begin{array}{l}\text { Did species composition vary } \\
\text { between seasons? }\end{array}$ & Ss & Yr & Free/no & 48.7 & & 5.16 & & 0.000 \\
\hline $\begin{array}{l}\text { Were there significant year*season } \\
\text { interactions? }\end{array}$ & $\mathrm{Yr}^{*} \mathrm{Ss}$ & PlotID & Free/Free & 41.7 & 6.25 & 5.14 & 0.000 & 0.000 \\
\hline
\end{tabular}

Environmental variables used in the test (Env.): vegetation type (Vg), grazer species (Gr), sampling year (Yr: 2005,2006 and 2007), season (Ss: late spring and midsummer). Covariables (Cov.): Vg, Gr, Yr and plot identifier coded as 12 dummy variables (PlotID). Permutation type on the whole plot/split plot level (Perm.). Percent of variability explained by all axes (\% exp.). Values of $F$ and $P$ on the first ( $F$ first and $P$ first) and on all ordination axes ( $F$ all and $P$ all $)$ for non-standardized test. 


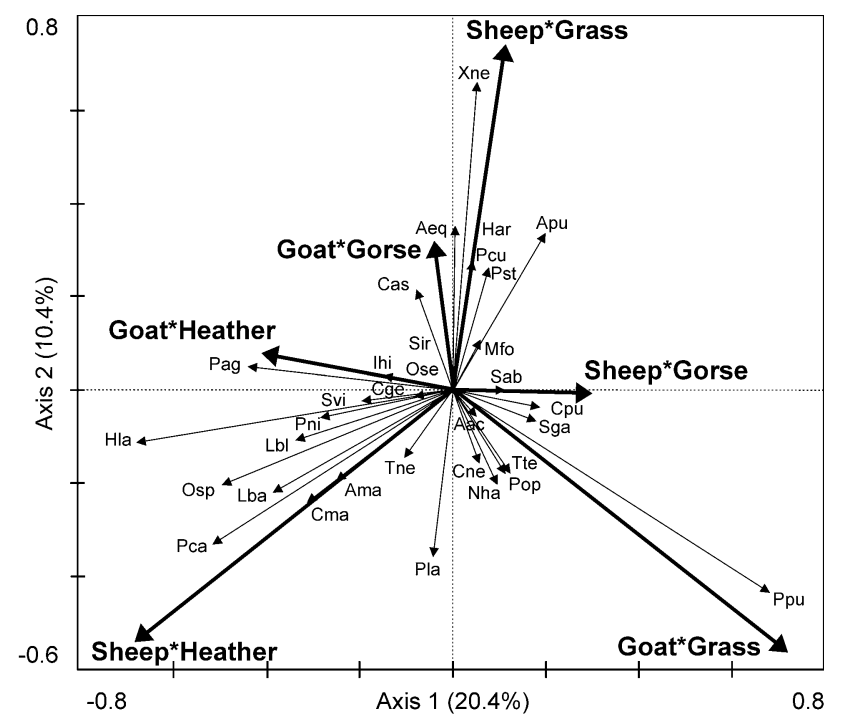

Fig. 3. Ordination diagram of ground-dwelling arthropod species based on a non-standardized RDA of the interaction between grazer species (goat or sheep) and type of vegetation (heather, gorse or grass dominated). For arthropod species abbreviations see Appendix.

sheep $(F=4.39, P<0.01)$ or goats $(F=2.21, P<0.05)$. The composition of the fauna varied among years $(P<$ $0.001)$ and also between seasons $(P<0.001)$. There was also a significant Year*Season interaction $(P<0.001)$.

Among the plant variables studied, herbaceous cover $(F$ $=4.50, P<0.05)$, heather cover $(F=4.35, P<0.01)$ and bare ground cover $(F=2.76, P<0.05)$ explained most of the variance in arthropod composition $(41.6 \%, F=4.20$, $P<0.001$ for the test of significance of all canonical axes). There is a gradient from areas with a high heather cover, (favoured by most harvestmen and carabids like Carabus macrocephalus Dejean, 1826), towards areas with a high herbaceous cover (preferred by the wolf spider P. pullata) or bare ground cover [favoured by the wolf spider Xerolycosa nemoralis (Westring, 1861)] (Fig. 4).

\section{DISCUSSION}

In the current study, arthropod community composition was mostly determined by the type of vegetation, rather than by the species of livestock. Univariate analyses indicate that the highest abundance and diversity of arthropods occurred in the heather dominated vegetation. Plant cover and height in heather dominated paddocks were clearly different from that in both gorse and grass dominated paddocks, regardless of the grazer species (Jáuregui et al., 2009). Multivariate analyses of the arthropod fauna also revealed that the composition of the fauna varied along a gradient from heather dominated towards gorse and finally grass dominated vegetation, as expected for a diverse group animals, which vary in seasonality, size, mobility, trophic level, life strategy and in their requirements for particular successional stages or structural characteristics of the vegetation (Southwood et al., 1979).

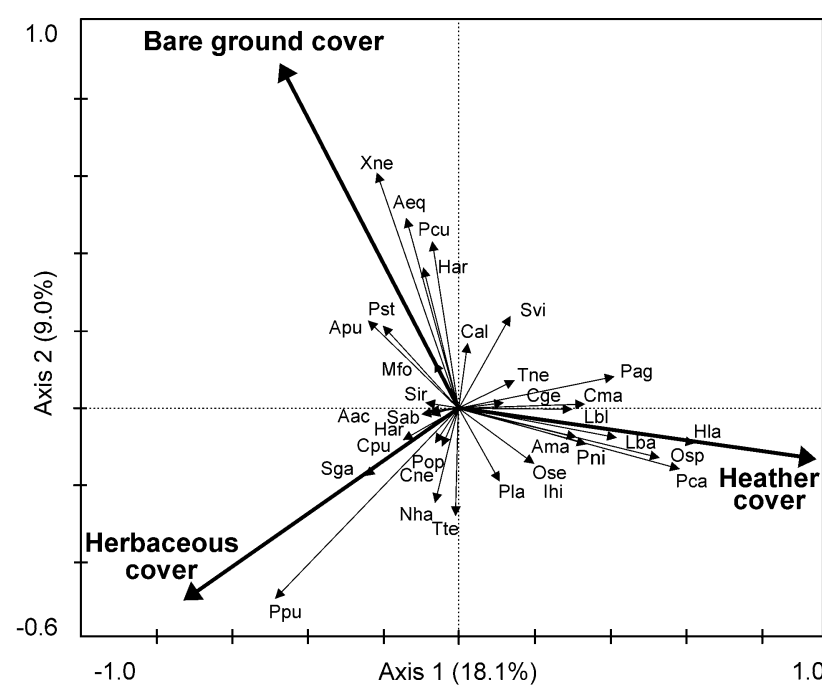

Fig. 4. Ordination diagram of ground-dwelling arthropod assemblages in relation to environmental variables (plant cover) after forward selection by RDA. For arthropod species abbreviations see Appendix.

The locomotory activity of some arthropod groups, such as Carabidae, might have influenced the results due to the location of the paddocks, although their size was estimated to be adequate for determining the effects of the various treatments on the fauna. Other groups, like wolf spiders and especially Opiliones, are known to be more sedentary and have a poor dispersal ability (Bragagnolo et al., 2007).

The high records for heather dominated vegetation might be related to its greater structural complexity, which might provide more foraging resources and protection from predators and extreme weather conditions (Riechert \& Gillespie, 1986) and overwintering habitats (Pfiffer \& Luka, 2000; Frank \& Reichhart, 2004). Typical forest carabid species like C. macrocephalus or Pterostichus cantaber (Chaudoir, 1868) (Taboada et al., 2004), frequently found on heathlands (Cuesta et al., 2008), and most of the harvestmen, which survive best at high humidities (Bragagnolo et al., 2007), are clearly associated with the heather dominated areas. The high records of arthropods in the heather dominated areas might also be due to less trampling and soil compactation in these areas, and the lack of burning in the past might have favoured the presence of vegetation at a more advanced successional stage.

Gorse dominated shrublands, despite being structurally complex, were less diverse than heather dominated areas (Jáuregui et al., 2009), which may partly explain their lower arthropod diversity. On the other hand, species such as $X$. nemoralis or Alopecosa pulverulenta, which rely on more open and xerophytic conditions, were present in the grass dominated shrublands (Harvey et al., 2002; Koponen, 2005).

Much of the variation in the community composition was also explained by the interaction between grazer species and vegetation type. Sheep and goats differ in their grazing behaviour and goats by controlling shrub 
encroachment (heather and gorse) more than sheep, promote grass growth (Radcliffe, 1985; Celaya et al., 2007). In the current study, heather dominated vegetation developed similarly in paddocks grazed by both grazer species, while within grass dominated paddocks goats clearly promoted higher percentages of herbaceous cover and sheep allowed the proliferation of gorse (Jáuregui et al., 2009). The response of the arthropod fauna accords with these results. The arthropod assemblages in heather dominated paddocks were similar irrespective of the grazer species, while in grass dominated paddocks the arthropod assemblages were different in the sheep and goat grazed paddocks (Fig. 3). Among the species that are clearly associated with a particular treatment, the wolf spider $P$. pullata, a common inhabitant of grasslands (Richter et al., 1971), was more abundant in grass dominated shrublands, especially those grazed by goats. High abundances of this species in heathland sites grazed intensively by goats is resported by Rosa García et al. (2009). In contrast, $H$. laranderas was abundant in the heather dominated paddocks, irrespective of the grazer species. High catches of this species are also recorded in less intensively goat grazed heathlands, i.e. with a high heather cover (Rosa García et al., 2009).

Irrespective of the grazer species or vegetation type, the total abundance of arthropods remained unaltered over time, although the activity-density of several groups and community composition changed between years and/or seasons. Yearly differences in assemblage structure are attributed to individual species responses to seasonal changes in weather conditions or other stochastic environmental variations (Davis et al., 2003; Wassenaar et al., 2005), but three years of weather data is insufficient for determining whether it was an important factor (Dennis et al., 2008). In addition, temporal changes in the vegetation might be expected to affect the fauna due to the associated changes in the structure of micro-habitats (Harvey et al., 2008).

In conclusion, in the present investigation, a higher global arthropod diversity and abundance was recorded in heather dominated vegetation than either grass or gorse dominated shrublands, which are less structurally complex and diverse and thus provide fewer habitats for arthropods. The faunal assemblages in heather dominated paddocks were similar irrespective whether they were grazed by goats or sheep but those in grass dominated paddocks differed. The gorse dominated vegetation, despite being structurally complex, did not have a specific and rich fauna like the heather dominated vegetation, and grazer species did not affect the arthropod assemblage associated with this vegetation. The present investigation underlines the importance of mature heathlands for maintaining abundant and diverse arthropod assemblages in such marginal areas compared to other vegetation types with a less diverse botanical composition.

ACKNOWLEDGEMENTS. This study was conducted as a part of the project AGL2003-05342 funded by the Ministry of Education and Science of Spain (CICYT). We are grateful to C. Prieto for providing valuable information on the Opiliones. We thank G. Pérez Trincado and Á. Rodríguez Tuñón for assistance with the field work. The authors would also like to acknowledge the staff at the experimental site for their support and efficient animal management.

\section{REFERENCES}

Álvarez M.A., García P. \& Valderrábano J. 2004. Tipificación, Cartografia y Evaluación de los Pastos Españoles: Cartografia de los Pastos de Asturias. SEEP, INIA, SERIDA, INDUROT, Oviedo, Spain, 138 pp.

Barrientos J.A. (ed.) 2004: Curso Practico de Entomología. CIBIO, AeE, UAB, Barcelona, Spain, 947 pp.

Bragagnolo C., Nogueira A.A., Pinto-da-Rocha R. \& Pardini R. 2007: Harvestmen in an Atlantic forest fragmented landscape: Evaluating assemblage response to habitat quality and quantity. Biol. Conserv. 139: 389-400.

BRown R. 1990: The biological interactions between heather management and conservation, shooting, grazing and recreation. In Whitby M. \& Grant S. (eds): Modelling Heather Management. Department of Agricultural Economics and Food Marketing, University of Newcastle, pp. 68-82.

Burnham K.P. \& Anderson D.R. 2002: Model Selection and Multimodel Inference. A Practical Information-Theoretic Approach. Springer, NewYork, 485 pp.

Celaya R., Martínez A. \& Osoro K. 2007: Vegetation dynamics in Cantabrian heathlands associated with improved pasture areas under single or mixed grazing by sheep and goats. Small Rumin. Res. 72: 165-177.

Celaya R., Benavides R., García U., Ferreira L.M.M., Ferre I., Martínez A., Ortega-Mora L.M. \& Osoro K. 2008: Grazing behavior and performance of lactating suckler cows, ewes and goats on partially improved heathlands. Animal 2: 1818-1831.

Cuesta D., Taboada A., Calvo L. \& Salgado J.M. 2008: Shortand medium-term effects of experimental nitrogen fertilization on arthropods associated with Calluna vulgaris heathlands in north-west Spain. Environ. Pollut. 152: 394-402.

Davis A.L.V., van Aarde R.J., Scholtz C.H. \& Delport J.F. 2003: Convergence between dung beetle assemblages of postmining vegetational chronosequence and unmined dune forest. Restor. Ecol. 11: 29-42.

Dennis P., Young M.R. \& Gordon I.J. 1998: Distribution and abundance of small insects and arachnids in relation to structural heterogenity of grazed, indigenous grasslands. Ecol. Entomol. 23: 253-264.

Dennis P., Young M.R. \& Bentley C. 2001: The effects of varied grazing management on epigeal spiders, harvestmen and pseudoscorpions of Nardus stricta grassland in upland Scotland. Agric. Ecosyst. Environ. 86: 39-57.

Dennis P., Skartveit J., McCracken D.I., Pakeman R.J., Beaton K., Kunaver A. \& Evans D.M. 2008: The effects of livestock grazing on foliar arthropods associated with bird diet in upland grasslands of Scotland. J. Appl. Ecol. 45: 279-287.

Duelli P., Obrist M.K. \& Schmats D.R. 1999: Biodiversity evaluation in agricultural landscapes: above-ground insects. Agric. Ecosyst. Environ. 74: 33-64.

Evans N., Gaskell P. \& Winter M. 2003: Re-assessing agrarian policy and practice in local environmental management: the case of beef cattle. Land Use Pol. 20: 231-242.

FARReLl L. 1989: The different types and importance of British heaths. Bot. J. Linn. Soc. 101: 291-299.

Forel J. \& Leplat J. 2001: Faune des Carabus de la Péninsule Ibérique. Collection Systemátique. Vol. 2. Magellanes, Paris, $172 \mathrm{pp}$. 
Frank T. \& Reichhart B. 2004: Staphylinidae and Carabidae overwintering in wheat and sown wildflower areas of different age. Bull. Entomol. Res. 94: 209-217.

GARDNER S.M. 1991: Ground beetle (Coleoptera: Carabidae) communities on upland heath and their association with heathland flora. J. Biogeogr. 18: 281-289.

Gardner S.M., Hartley S.E., Davies A. \& Palmer S.C.F. 1997: Carabid communities on heather moorlands in northeast Scotland: the consequences of grazing pressure for community diversity. Biol. Conserv. 81: 275-286.

Gibson C.W.D. \& BRown V.K. 1991: The effects of grazing on local colonisation and extinction during early sucesión. $J$. Veg. Sci. 2: 291-300.

Gibson C.W.D., Brown V.K., Losito L. \& McGavin G.C. 1992a: The response of invertebrate assemblies to grazing. Ecography 15: 166-176.

Gibson CW.D., Hambler C. \& Brown V.K. 1992b: Changes in spider (Araneae) assemblages in relation to succession and grazing management. J. Appl. Ecol. 29: 132-142.

Gimingham C.H. 1992. The Lowland Heathland Management Handbook. English Nature Science Series 8. English Nature, Peterborough, UK, $201 \mathrm{pp}$.

González-Megías A., Gómez J.M. \& Sánchez Piñero F. 2004: Effects of ungulates on epigeal arthropods in Sierra Nevada National Park (southeast Spain). Biodivers. Conserv. 13: 733-752.

Grant S.A. 1981: Sward components. In Hodgson J., Baker R.D., Davies A., Laidlaw A.S. \& Leaver J.D. (eds): Sward Measurement Handbook. British Grassland Society, Hurley, Maidenhead, Berkshire, UK, pp. 71-92.

Harvey J.A., van der Putten W.H., Turin H., Wagenaar R. \& Bezemer T.M. 2008: Effects of changes in plant species richness and community traits on carabid assemblages and feeding guilds. Agric. Ecosyst. Environ. 127: 100-106.

Harvey P.R., Nellist D.R. \& Telfer M.G. 2002: Atlas of British Spiders (Arachnida, Araneae) Vols 1 and 2. Biological Records Centre, Huntingdon, UK, 406 pp.

Jáuregui B.M., Celaya R., García U. \& Osoro K. 2007: Vegetation dynamics in burnt heather-gorse shrublands under different grazing management with sheep and goats. Agroforest. Syst. 70: 103-111.

Jáuregui B.M., García U., Osoro K. \& Celaya R. 2009: Sheep and goat grazing effects on three Atlantic heathland types. Rangeland Ecol. Manag. 62: 119-126.

LEPŠ J. \& ŠMILAUER P. 2003: Multivariate Analysis of Ecological Data using CANOCO. Cambridge University Press, Cambridge, $269 \mathrm{pp}$.

Martens J. 1978: Spinnentiere, Arachnida-Weberknechte, Opiliones. Die Tierwelt Deutschlands. Vol. 64. Fischer, Jena, $464 \mathrm{pp}$.

Mommertz S., Schauer C., Kösters N., Lang A. \& Filser J. 1996: A comparison of D-Vac suction, fenced and unfenced pitfall trap sampling of epigeal arthropods in agro-ecosystems. Ann. Zool. Fenn. 33: 117-124.

Morris M.G. 1990: The effects of management on the invertebrate community in calcareous grassland. In Hillier S.H., Walton D.W.H. \& Wells D.A. (eds): Calcareous Grasslands. Ecology and Management. Bluntisham, Huntingdon, UK, pp. 128-133.

Newton A.C., Stewart G.B., Myers G., Diaz A., Lake S., BulLOCK J.M. \& PULLIN A.S. 2009: Impacts of grazing on lowland heathland in nort-west Europe. Biol. Conserv. 142: 935-947.

Ortuño V.M. \& Marcos J.M. 2003: Los Caraboidea (Insecta, Coleoptera) de la Comunidad Autónoma del País Vasco (I). Servicio Central de Publicaciones del Gobierno Vasco, Vitoria, Spain, 573 pp.
Osoro K., Vassallo J.M., Celaya R. \& Martínez A. 1999: Livestock production systems and the vegetation dynamics of Less Favoured Areas (LFAs): developing viable systems to manage semi-natural vegetation in temperate LFAs in Spain. In Laker J.P. \& Milne J.A. (eds): Livestock Production in the European Less Favoured Areas. Macaulay Land Use Research Institute, Aberdeen, UK, pp. 133-143.

Osoro K., Ferreira L.M.M., García U. \& Celaya R. 2009: Performance of domestic herbivores in marginal heathlands. In New Trends for Innovation in the Mediterranean Animal Production. Xth Mediterranean Symposium. INRA-EAAPCIHEAM, Corte, Corsica, France. In press.

Pfiffner L. \& LuKa H. 2000: Overwintering of arthropods in soils of arable fields and adjacent semi-natural habitats. Agric. Ecosyst. Environ. 78: 215-222.

Piessens K. \& Hermy M. 2006: Does the heathland flora in north-western Belgium show an extinction debt? Biol. Conserv. 132: 382-394.

RADCLIFFE J.E. 1985: Grazing management of goats and sheep for gorse control. N. Z. J. Exp. Agric. 13: 181-190.

Rainio J. \& Niemelä J. 2003: Ground beetles (Coleoptera: Carabidae) as bioindicators. Biodivers. Conserv. 12: 487-506.

Richter C.J.J., DEN Hollander J. \& Vlijm L. 1971: Differences in breeding and motility between Pardosa pullata (Clerck) and Pardosa prativaga (L. Koch), (Lycosidae, Araneae) in relation to habitat. Oecologia 6: 318-327.

Riechert S.E. \& Gillespie R.G. 1986: Habitat choice and utilization in web-building spiders. In Shear W.A. (eds): Spiders: Webs, Behavior and Evolution. Stanford University Press, CA, pp. 23-48.

RoBerts M.J. 1993: The Spiders of Great Britain and Ireland, Compact Edition. Harley Books, Colchester, UK, 705 pp.

RoBERTS M.J. 1995: Collins Field Guide to Spiders of Britain and Northern Europe. Harper Collins, London, 383 pp.

Rosa García R., Jáuregui B.M., García U., Osoro K. \& Celaya R. 2009: Effects of livestock breed and grazing pressure on ground-dwelling arthropods in Cantabrian heathlands. Ecol. Entomol. 34: 466-475.

SANKEY J.H.P. \& SAVORY T.H. 1974: British Harvestmen. Arachnida: Opiliones. Keys and Notes for the Identification of the Species. Synopsis of the Bristish Fauna No. 4. The Linnean Society of London, Academic Press, London, 76 pp.

SAS Institute 1999: SAS/STAT User's Guide. Version 8. SAS Institute Inc., Cary, North Carolina.

Simon E. 1879: Les Arachnides de France, Opiliones. Vol. 7. Librarie Encyclopédique de Roret, Paris, 189 pp.

Southwood T.R.E., Brown V.K. \& Reader P.M. 1979: The relatioships of plant and insect diversities in succession. Biol. J. Linn. Soc. 12: 327-348.

Taboada A., Kotze D.J. \& Salgado J.M. 2004: Carabid beetle occurrence at the edges of oak and beech forests in NW Spain. Eur. J. Entomol. 101: 555-563.

Ter Braak C.J.F. \& Šmilauer P. 2002: CANOCO Reference Manual and CanoDraw for Windows User's Guide: Software for Canonical Community Ordination (Version 4.5). Microcomputer Power, Ithaca, NY.

Thompson D.B.A., MacDonald A.J., Marsden J.H., Galbraith C.A. 1995: Upland heather moorland in Great Britain: a review of international importance, vegetation change and some objectives for nature conservation. Biol. Conserv. 71: $163-178$.

Uetz G.W. \& Unzicker J.D. 1976: Pitfall trapping in ecological studies of wandering spiders. J. Arachnol. 3: 101-111.

Vohland K., Uhlig M., Marais E., Hoffmann A. \& Zeller U. 2005: Impact of different grazing systems on diversity, abundance and biomass of beetles (Coleoptera), a study from 
southern Namibia. Mitt. Mus. Nat. Kd. Berl., Zool. Reihe 81: $131-143$.

Wassenaar T.D., van Aarde R.J., Pim S.L. \& Ferreira S.M. 2005: Community convergence in disturbed subtropical dune forests. Ecology 86: 655-666.
Wettstein W. \& Schmid B. 1999: Conservation of arthropod diversity in montane wetlands: effect of altitude, habitat quality and habitat fragmentation on butterflies and grasshoppers. J. Appl. Ecol. 36: 363-373.

Received November 10, 2009; revised and accepted December 22, 2009

APPENDIX. Total number of individuals of each species of Lycosidae, Opiliones and Carabidae collected in each of three types of Cantabrian heathland (heather, gorse and grass dominated). Data from four paddocks per vegetation type and 12 pitfall traps per paddock operated over five days in 2005, 2006 and 2007 were pooled.

\begin{tabular}{|c|c|c|c|c|}
\hline Taxa and species & Abbr. & Heather & Gorse & Grass \\
\hline \multicolumn{5}{|l|}{ ARANEAE, LyCOSIDAE: } \\
\hline Alopecosa accentuata (Latreille, 1817) & $A a c$ & 6 & 7 & 8 \\
\hline Alopecosa pulverulenta (Clerck, 1757) & Apu & 25 & 22 & 45 \\
\hline Pardosa nigriceps (Thorell, 1856) & Pni & 26 & 10 & 10 \\
\hline Pardosa pullata (Clerck, 1757) & Ppu & 7 & 23 & 66 \\
\hline Trochosa terricola Thorell, 1856 & Tte & 8 & 10 & 6 \\
\hline Xerolycosa nemoralis (Westring, 1861) & Xne & 8 & 19 & 28 \\
\hline \multicolumn{5}{|l|}{ OPILIONES: } \\
\hline \multicolumn{5}{|l|}{ Sironidae } \\
\hline Iberosiro sp. & Sir & 0 & 2 & 0 \\
\hline \multicolumn{5}{|l|}{ Ischyropsalididae } \\
\hline Ischyropsalis hispanica Roewer, 1953 & Ihi & 1 & 0 & 0 \\
\hline \multicolumn{5}{|l|}{ Sabaconidae } \\
\hline Sabacon franzi Roewer, 1953 & $S a b$ & 0 & 1 & 0 \\
\hline \multicolumn{5}{|l|}{ Nemastomatidae } \\
\hline Nemastoma hankiewiczii (Kulczynski, 1909) & Nha & 7 & 6 & 10 \\
\hline \multicolumn{5}{|l|}{ Trogulidae } \\
\hline Trogulus nepaeformis (Scopoli, 1763) & Tne & 1 & 1 & 0 \\
\hline \multicolumn{5}{|l|}{ Leiobunidae } \\
\hline Leiobunum blackwalli Meade, 1861 & $L b l$ & 4 & 1 & 0 \\
\hline \multicolumn{5}{|l|}{ Phalangiidae } \\
\hline Odiellus seoanei (Simon, 1878) & Ose & 1 & 0 & 0 \\
\hline Odiellus spinosus (Bosc, 1972) & Osp & 35 & 13 & 5 \\
\hline Paroligolophus agrestis (Meade, 1855) & Pag & 18 & 2 & 3 \\
\hline Phalangium opilio Linnaeus, 1758 & Pop & 6 & 4 & 15 \\
\hline \multicolumn{5}{|l|}{ Sclerosomatidae } \\
\hline Homalenotus laranderas Grasshoff, 1959 & $H l a$ & 57 & 17 & 6 \\
\hline \multicolumn{5}{|l|}{ Coleoptera, Carabidae: } \\
\hline Amara equestris (Duftschmid, 1812) & Aeq & 1 & 3 & 2 \\
\hline Amara sp. & Ama & 1 & 0 & 0 \\
\hline Calathus asturiensis Vuillefroy, 1866 & Cas & 1 & 0 & 1 \\
\hline Carabus nemoralis O.F. Müller, 1764 & Cne & 1 & 2 & 1 \\
\hline Carabus macrocephalus Dejean, 1826 & Cma & 48 & 4 & 4 \\
\hline Carabus getschmanni Lopouge, 1924 & Cge & 3 & 5 & 0 \\
\hline Carabus purpurascens Fabricius, 1787 & Cpu & 0 & 5 & 1 \\
\hline Harpalus spp. & Har & 0 & 1 & 1 \\
\hline Leistus barnevillei Chaudoir, 1867 & $L b a$ & 3 & 0 & 0 \\
\hline Metabletus foveatus (Geoffroy, 1785) & $M f_{o}$ & 2 & 3 & 2 \\
\hline Platyderus sp. & Pla & 2 & 0 & 2 \\
\hline Poecilus cupreus (Linnaeus, 1758) & $P c u$ & 0 & 0 & 1 \\
\hline Pterostichus cantaber (Chaudoir, 1868) & $P c a$ & 29 & 1 & 5 \\
\hline Pterostichus strenuus (Panzer, 1796) & Pst & 1 & 2 & 3 \\
\hline Steropus gallega (Fairmaire, 1859) & $S g a$ & 0 & 1 & 1 \\
\hline Synuchus vivalis (Illiger, 1798) & $S v i$ & 2 & 0 & 1 \\
\hline
\end{tabular}

Note: Abbr., abbreviations used for species identification in Figs 1, 2, and 3. 